\title{
SPRAWOZDANIE Z OGÓLNOPOLSKIEJ KONFERENCJI NAUKOWEJ: „LITURGIA - ZAANGAŻOWANIE CIAŁA - ZAANGAŻOWANIE DUCHA?" W ARCYBISKUPIM SEMINARIUM DUCHOWNYM W POZNANIU 3 MARCA 2018 ROKU
}

W ramach I Ogólnopolskiego Forum Ceremoniarzy Wyższych Diecezjalnych Seminariów Duchownych, organizowanego przez Uniwersytet im. Adama Mickiewicza w Poznaniu, Wydział Teologiczny, Zakład Liturgiki i Homiletyki i Arcybiskupie Seminarium Duchowne w Poznaniu, w dniach od 2 do 4 marca, odbyła się ogólnopolska konferencja naukowa zatytułowana „Liturgia - zaangażowanie ciała - zaangażowanie ducha?”. Konferencję zorganizowano 3 marca 2018 roku w Arcybiskupim Seminarium Duchownym w Poznaniu na Wydziale Teologicznym. Organizatorami konferencji byli: ks. prof. UAM dr hab. Dariusz Kwiatkowski oraz alumni Arcybiskupiego Seminarium Duchownego w Poznaniu: Szymon Jakób, Filip Michałkowski, Wojciech Nowak, Paweł Napierała, Amadeusz Fertig, Jakub Proch i Dawid Wojdowski. Jako główny cel konferencji organizatorzy postawili przede wszystkim pomoc w bardziej świadomym przeżywaniu liturgii, formację naukową, wymianę doświadczeń liturgicznych oraz integrację alumnów z różnych seminariów. Odkrycie mistagogii liturgii wydaje się dziś bardzo potrzebne, gdyż często jest ona przeżywana 
bez zaangażowania zarówno ze strony wiernych, jak i duchownych. Brak zaangażowania i zrozumienia liturgii przez wiernych świeckich najczęściej prowadzi do jej zaniedbywania. Konferencja, podczas której wygłoszono 17 referatów, miała także na celu dostarczenie konkretnych pomocy dla angażujących się w liturgię (ceremoniarzy, kleryków, ministrantów) w jej głębszym i bardziej świadomym przeżywaniu.

Konferencję rozpoczęła koncelebrowana Msza Święta pod przewodnictwem JE ks. bpa Adama Bałabucha. Otwarcia konferencji dokonał ks. prof. UAM dr hab. Paweł Wygralak - Dziekan Wydziału Teologicznego Uniwersytetu im. Adama Mickiewicza w Poznaniu. Następnie bs. bp Adam Bałabuch przedstawił aktualne prace Komisji ds. Kultu Bożego i Dyscypliny Sakramentów.

Pierwszy referat wygłosiła s. prof. UPJP II dr hab. Adelajda Sielepin (UPJP II Kraków) na temat duchowości liturgicznej ceremoniarza. W swoim wystąpieniu podjęła próbę odpowiedzi na pytania: kim jest ceremoniarz i jakie funkcje sprawuje w liturgii. Posługa ceremoniarza została przedstawiona w ujęciu historycznym i teologicznym. Ceremoniarz jest nie tylko odpowiedzialny za przygotowanie i kierowanie liturgią, ale jest przede wszystkim świadkiem misterium uobecnianego w każdej celebracji liturgicznej.

Ks. dr Jakub Dębiec z Gniezna mówił o konieczności zaangażowanie ducha i ciała w liturgii. Tylko angażując całego siebie w celebrację liturgiczną, można ją głęboko i owocnie przeżyć.

Ks. prof. UMK dr hab. Daniel Brzeziński (UMK Toruń) podjął zagadnienie prawa w liturgii. Mówił o relacji między duchem i literą. Normy liturgiczno-prawne porządkują liturgię. Stoją nade wszystko na straży czystości celebrowanej wiary i gwarantują poprawność doktrynalno-liturgiczną sprawowanych misteriów. Tak starano się pojmować prawo w przeszłości (co prawda, w tych wysiłkach popadano czasem w skrajny rubrycyzm i niemalże utożsamiano liturgikę z rubrycystyką), i tak należy je postrzegać dzisiaj. Należy podkreślić, że czynności liturgiczne nie są czynnościami prywatnymi, lecz dziełem Chrystusa i Kościoła.

Ks. prof. UAM dr hab. Dariusz Kwiatkowski z Wydziału Teologicznego Uniwersytetu im. Adama Mickiewicza w Poznaniu przedstawił referat zatytułowany: „W świecie liturgicznych postaw i gestów wyrażających zbawczy dialog Boga ze zgromadzeniem liturgicznym”. W swojej 
prezentacji ukazał bogactwo postaw i gestów liturgicznych. Autor omówił ich właściwe miejsce w liturgii oraz ich biblijno-patrystyczne źródła. Wiele znaków ma także zakorzenienie antropologiczne i wyraża naturalne zachowania człowieka. Postawy i gesty ukazane są jako znaki prowadzące do dialogu Boga z człowiekiem, który dokonuje się w liturgii Kościoła. Artykuł jest solidnym i naukowym przedstawieniem symboliki gestów i znaków liturgicznych.

Ks. dr Andrzej Megger (KUL Lublin) przedstawił referat zatytułowany: „Odkryć Nieznanego. Duch Święty sprawcą liturgii”. W swoim wystąpieniu ukazał liturgię jako dzieło Trójcy Świętej ze szczególnym uwzględnieniem obecności i działania Ducha Świętego. Słusznie podkreślał, że bez Niego liturgia jest jedynie rytuałem. Wszystko w Kościele, a więc liturgia, wierni, przepowiadanie, dzieła miłości, jest połączonym działaniem Ducha i przemienianego przez Niego człowieczeństwa. Ta boska synergia objawia się nie tylko w celebracji, ale i życiu, prowadząc do tego, że życie człowieka staje się liturgią.

W drugiej części konferencji swoje referaty prezentowali ceremoniarze $\mathrm{z}$ różnych polskich seminariów. Amadeusz Fertig zatytułował swoje wystąpienie: „Opowiem wam dowcip... Humor podczas liturgii”. W referacie podjął bardzo ważny problem, który można zaobserwować w wielu kościołach podczas sprawowanej liturgii. Kapłani, szukając taniej popularności, banalizują liturgię i spłycają ją przez wprowadzanie piosenek nieliturgicznych, teatralnych zachowań, banalnego języka opowiadanie dowcipów. To wszystko zasłania głównego Liturga, którym jest Jezus Chrystus i spłyca sens sprawowanego misterium. W referacie jasno pokazane są granice, których celebransowi nie można przekroczyć, a z drugiej strony przedstawia się liturgię jako celebrację wypełnioną radością wypływającą z faktu spotkania z Chrystusem zmartwychwstałym.

Dawid Wojdowski mówił o milczeniu jako sposobie zaangażowania człowieka w liturgię Kościoła. Referent podjął bardzo ważny znak liturgiczny, którym jest milczenie. Niestety, wciąż jest to znak zaniedbywany i niedoceniony. Często można odnieść wrażenie, że celebrans i zgromadzenie liturgiczne nie mają czasu na milczenie lub sobie z nim nie radzą. Tymczasem milczenie jest życiem liturgii. Jest jej fundamentem. W ciszy nie tylko człowiek spotyka się sam ze sobą, lecz także jest to również miejsce relacji z Bogiem. Milczenie jest dane po to, by uczyć 
się lepszej, wytrwalszej, głębszej modlitwy. Pojawia się ono w liturgii, by we wspólnocie łączyć się w kontemplacji nad tajemnicami wiary. Cisza użyźnia liturgię i daje zadatek nieba.

Filip Michałkowski ukazał, czym jest przeżywanie liturgii według św. Josemaríi Escrivy. W swoim wystąpieniu przedstawił rozumienie i przede wszystkim przeżywanie Eucharystii przez św. Josemaríę Escrivę. Dla niego każda Eucharystia stanowiła tajemnicę wiary i czas na najbardziej głęboką modlitwę rozumianą jako spotkanie z Chrystusem zmartwychwstałym. Uczyła go także nieustannego składania ofiary z własnego życia i łączenia jej z ofiarą Chrystusa. Eucharystia jest szkołą uwielbienia i modlitwy.

Jakub Proch wygłosił referat zatytułowany: „Maryja w liturgii na przykładzie czcigodnego sługi Bożego Stefana kardynała Wyszyńskiego”. Przypomniał najpierw, że św. Jan Paweł II nazwał Maryję „Niewiastą Eucharystii”. Następnie, opierając się na nauczaniu kardynała Stefana Wyszyńskiego, pokazał, w jaki sposób Maryja pomaga w uczestnictwie i przeżywaniu Eucharystii. W drodze odkrywania wstawiennictwa Najświętszej Panny omówione zostały objawienia mistyczne Cataliny Rivas oraz sposób przeżywania Eucharystii, wraz z Maryją, przez Sługę Bożego Kardynała Stefana Wyszyńskiego, który Maryi oddał się w macierzyńską niewolę i z Nią kroczył przez swoje kapłańskie życie.

Witold Morozowicz mówił o Diecezjalnym Kongresie Eucharystyczny w Kaliszu i jego znaczeniu dla pobożności eucharystycznej. W referacie został omówiony przebieg Diecezjalnego Kongresu Eucharystycznego Diecezji Kaliskiej, który odbył się w 2015 roku. Na początku została przedstawiona historia kongresów eucharystycznych. Następnie omówił przygotowania do obchodów kongresu, ze szczególnym uwzględnieniem artykułów dotyczących Eucharystii zamieszczonych w „Opiekunie”. W końcu zrelacjonował przebieg kongresu począwszy od sympozjum liturgicznego, poprzez stacje kongresowe w parafiach Kalisza i Ostrowa, aż do procesji i uroczystej Mszy Świętej w Kaliszu pod przewodnictwem Księdza Arcybiskupa Piero Mariniego.

Mateusz Włosiński podjął się tematu dotyczącego miejsca i roli ołtarza w w liturgii. Swoje wystąpienie zatytułował: „Nowy byt, choć tak dobrze znany”. Czynności sakralne, w każdej religii, ze swej natury związane są z osobą kapłana i z ołtarzem, na którym składa on ofiarę. Ołtarz 
stanowi miejsce spotkania tego, co ludzkie z tym, co boskie. To spotkanie w chrześcijaństwie dokonuje się m. in. dzięki osobie celebransa, który na mocy swojej posługi, tworzy z ołtarzem głębszą wspólnotę, niż seksualne zjednoczenie małżonków. To zjednoczenie wymaga od niego poświęceń rozciągniętych na całe jego życie, ale też wydaje owoc, który oddziałuje na grupę osób większą niż rodzina. W konsekwencji liturgia jawi się jako uobecnienie ofiary z siebie, którą dokonał Jezus na Krzyżu.

Paweł Napierała przedstawił referat zatytułowany: „Gest pokłonu w przeżywaniu liturgii”. W swoim wystąpieniu mówił w sposób bardzo szczegółowy o stosowanym w liturgii geście pokłonu lub skłonu. Gest pomaga w głębszym i piękniejszym przeżyciu liturgii. Gest pokłonu dobitnie wskazuje, Komu należy się cześć i wyrazy szacunku, oraz przed Kim trzeba okazywać skruchę. Symbolika tego gestu wyraźnie wskazuje i przypomina o tym, by zawierzać siebie Panu i starać się wykonywać w swoim życiu Jego świętą wolę. Wnikliwe poznanie znaczenia gestu pokłonu w liturgii z pewnością ułatwi uczestnictwo w celebracji i pozwoli dostrzec głębię poszczególnych jej części.

Szymon Jakób podjął bardzo ważny i aktualny temat dotyczący używania urządzeń elektronicznych w liturgii. Po zarysowaniu tła historycznego używania tych środków, dokonał analizy konsekwencji ich używania. Następnie zaprezentował wynik sondażu na temat używania najnowszych urządzeń elektronicznych do modlitwy brewiarzowej. Artykuł wykazuje bezzasadność wprowadzania tychże do celebracji publicznych.

Wojciech Nowak przedstawił w swoim wystąpieniu znaczenie i symbolikę krzyża w liturgii. W referacie akcentował, że znak krzyża obecny w tak wielu aspektach - w gestach, mowie, symbolice, architekturze, sztuce - jednoznacznie wskazuje na osobę samego Zbawiciela oraz Jego rolę, jaką spełnił w dziele odkupienia. Podkreślił, że warto podczas uczestniczenia w zgromadzeniach liturgicznych przez pryzmat krzyża realizować swoje czynne i świadome uczestnictwo w świętych misteriach. Symbol męki Syna Bożego może pozwolić na głębsze partycypowanie człowieka w tym, co święte.

Jakub Fotin przedstawił referat zatytułowany: „Obrzęd pojednania wielu penitentów z indywidualną spowiedzią - wyrazem zaangażowania ducha czy ciała?”. W swoim wystąpieniu mówił o obrzędzie pojednania wielu penitentów z indywidualną spowiedzią i rozgrzeszeniem. Na po- 
czątku zostało przedstawione teologiczne tło sakramentu pokuty i jego wymiar eklezjalny. Podkreślone zostały niepokojące tendencje związane z niewłaściwym podchodzeniem do tego sakramentu. Dokonał również analizy tejże celebracji liturgicznej z uwydatnieniem owoców, jakie płyną z głębokiego i wiernego podejścia do sprawowania sakramentu pokuty i pojednania zarówno od strony penitenta, jak i spowiednika.

I Ogólnopolskie Forum Ceremoniarzy Wyższych Diecezjalnych Seminariów Duchownych oraz świeckich ceremoniarzy z archidiecezji poznańskiej i diecezji kaliskiej (istnieją tu kursy i szkoły ceremoniarzy) było inicjatywą bardzo potrzebną i udaną. Przez trzy dni jej uczestnicy przechodzili formację duchową, naukową i praktyczną. Referaty wygłoszone podczas konferencji naukowej były bardzo ciekawe i dotyczyły w większości aktualnych zagadnień dotyczących życia liturgicznego, które wciąż jest narażane na nadużycia i błędy (świadczyła o tym dyskusja tocząca się po wygłoszonych referatach). Z wygłoszonych referatów wypływała wielka troska ich autorów o piękno i poprawność w sprawowaniu liturgii Kościoła. Bardzo cieszy fakt, że w konferencję byli zaangażowani ceremoniarze seminaryjni i parafialni oraz grupa profesorów od lat zajmujących się teologią liturgii. Zamiarem organizatorów jest cykliczne organizowanie tego typu spotkań. Wstępnie ustalono, że będą się one odbywały co dwa lata. 